\title{
A study of the difficulties that preschool teachers' experience in performance of musical activities in terms of various variables ${ }^{1}$
}

\author{
Ilg1m Kılıç ${ }^{2}$ \\ Şefika Topalak ${ }^{3}$ \\ Tarkan Yazıci ${ }^{4}$
}

\begin{abstract}
Music education in preschool period is of capital importance to allow individual to use basic education and develop positive attitude to music. The reason is that preschool education provides rich-stimulant environments that are suitable for development level and personal characteristics of early-aged individuals, and helps them to develop themselves in mental, physical, emotional and social terms, and also braces them for primary education. For this reason, the quality of musical activities by preschool teachers and the difficulties become crucial. This study, as a qualitative research, has focused on 20 teachers, commissioned in official preschool institutions in TrabzonCity Centrum during 2013-2014 education period, and it's been determined that teachers experience the difficulties due to musical activity applications, characteristics of teachers and inservice education needs.
\end{abstract}

Keywords: Preschool; music; musical activity.

\section{Introduction}

The first and most important period of education is preschool period. Principally, this includes the period from the birth to primary school, supports the development of children with related ages and also requires certain targets for children education (Ömeroğlu, 1997). Preschool period is an education period that the things learned by children are never forgotten, and that the children complete their physical, psychomotor, socio-emotional, mind-language developments-playing important role for their future-, and that shapes their characters and prepare the children for primary education, a higher level after preschool period (Ömeroğlu and Yaflar, 2004; Erden,1998; Ünlü, 2001). In this period, which is also called "Early Childhood Education", materialization of the development of the children in line with cultural values of society, increasing the development of their emotions and perceptions, developing their creativity, allowing them express themselves, providing them loyalty to their national, moral, ethical, cultural and humanistic values and enabling self-control and gain independence takes place (Taner Derman and Başal, 2010). A number of studies have found that music plays a critical role in early childhood education. It is a collective activity that can encourage social and emotional learning (Eisner, 2001).

\footnotetext{
${ }^{1}$ This study was orally presented in 2014 ERPA International Fine Arts and Music Congress.

${ }^{2}$ Associate Professor, Başkent University, Faculty of Education, Department of Primary Education, ilgimkilic@gmail.com

${ }^{3}$ Teaching Assistant, KTU, Faculty of Education, Department of Fine Arts, sefikat@gmail.com

${ }^{4}$ Assistant Professor, Mersin University, Faculty of Education, Department of Fine Arts, tyazici@mersin.edu.tr
} 
Kılıç, I., Topalak, Ş., \& Yazıcı, T. (2017). A study of the difficulties that preschool teachers' experience in performance of musical activities in terms of various variables. Journal of Human Sciences, 14(1), 441-456. doi:10.14687/ihs.v14i1.4272

Preschool education that includes the period of basic knowledge, skills and habits shouldn't be left to its fate, contrary to this, it should be managed scientifically and systematically. This education should allow individuals to stably adapt to their environment. Consequently, this adaptation can be provided only in preschool period. For this reason, preschool education that is the most important and primary step of our education system has vital importance for the future of the country (Ünlü, 2001). The reason is that basic goal of preschool education to grow healthy generations who are modern, entrepreneur, researcher; who freely express their emotions and minds; who provide their self-control; who respect to their and people's rights; who can use their skills; who have their cultural values (Oktay and Zembat, 1994). In this scope, the quality of education in preschool institutions has an importance as the first formal education step that depends on success level of children. A healthy music education that is given from childhood period shall be able to make individuals more successful and happier in their lives. As de l'Etoile (2001) mentioned when teachers or caregivers received qualified music education, the children in their care demonstrated increases in visual, vocal, and physical engagement behaviors. Since all education institutions are close to each other and they have mutual positive-negative impacts, the difficulties against preschool teachers in performance of musical activities have crucial importance (Oğuz, 2004). The reason is that music education has an importance place in preschool education. Music education helps cognitive, affective, kinesthetic and social developments of children, and the music with esthetical language allows them to their emotions, minds and impressions; accordingly children can show own creativity, and also development of mother tongue is provided (Özal Göncü, 2010). When young children are provided with musical activities, they are given the opportunity to develop creatively (Paquette \& Rieg, 2008). According to Epstein (2001); a child can sense himself/herself and the world in a creative way because of music education in preschool period; is thinking of relations over the world and construing his/her life. Also music can be a joyful and aesthetic form of play in which young children innately want to be involved (Kyoung Kim, 2013). However, when the related literature is reviewed, it becomes evident that the preschool teachers experience various difficulties in performing musical activities and thus fail to systematically perform the activities (Karaküçük, 2008; Köksoy and Taş, 2005; Özkut and Kaya, 2012; Göncü, 2009; Ersoy andDere, 2012). For this reason, determining and assessing the difficulties against preschool teachers in performance of music activities are aimed in this research. In order to provide a basis for the future studies and to contribute to addressing the ongoing difficulties, the problem sentence of the research is determined as "what are the difficulties that preschool teachers experience in performance of music activities?".

\section{Method}

In this section information is provided on research model, sample group of the research, data collection tool and data analysis.

\section{1.Research Model}

In this research, phenomenological pattern is used as part of the qualitative research method. Phenomenological pattern focuses on phenomena faced by individuals as events, experiences, perceptions, tendencies, conceptions and situations which are not recognized but intimately sensed in detail. The studies aimed at researching and explaining non-extrinsic phenomena, which are not completely comprehended by individuals, underlie phenomenology (Yıldırım and Şimşek, 2011: 72).

\section{2. Sample Group of Research}

In this research, purposeful sampling method is used. The reason behind the selection of this method of sampling is to have deep and detailed information about the difficulties experienced by preschool teachers in performance of musical activities. According to Patton (1987) this sampling 
Kılıç, I., Topalak, Ş., \& Yazıcı, T. (2017). A study of the difficulties that preschool teachers' experience in performance of musical activities in terms of various variables. Journal of Human Sciences, 14(1), 441-456. doi:10.14687/ihs.v14i1.4272

method facilitates making accurate generalizations about the universe and enables thorough studies on cases which are supposed to have substantial knowledge. Hence, it is practical for discovering and explaining the phenomena and incidents in most cases (in Yıldırım and Şimşek, 2011: 107). This research has been carried out with 20 teachers who are charged in Ministry of National Education associate official preschool institutions in Trabzon-center during 2013-2014 education period by performing interviews. $100 \%$ of teachers participated to the research are female $(\mathrm{n}=20)$. Professional levels of teachers are as; $25 \%(n=5)$ less than 5 years, $50 \%(n=10) 5-10$ years, $15 \%$ $(n=3) 11-15$ years, $10 \%(n=2) 16$ years and over. $9(45 \%)$ of teachers in research group graduated from Faculty of Education; 2 (10\%) graduated from Faculty of Occupational Training and $9(45 \%)$ graduated from Faculty of Extended Education.

\section{3. Data Collection Tool}

Through interviews, in depth information is gathered about a specific issue and all dimensions of the studied subject come into light (Çepni, 2009: 143). This is because, "the actual and deep" meanings of what was said in the interviews unfold together with their superficial meanings. Tone of voice and gesture during the interviews and the willingness to answer questions have the characteristics of cue for assessing what was said, sorting wrong answers and unfolding the facts (Karasar, 2012: 166). From this aspect, it removes the limitedness and artificiality of the tests/surveys depending on writing or filling up (Yıldırım and Şimşek, 2011: 127). For this purpose, semi-configured interview method is applied in this research which is patterned in accordance with qualitative research process. The validity of the interview form is provided by development of semiconfigured form in accordance with the comments of three academic members. Thereafter, pilot applications were performed and interview forms were finalized for interviews in compliance with all these results. Interviews were performed in the form of asking the questions in the interview form to each participant and recording the answers via tape recorders. Interviews, which were performed once for each participant, lasted 45 minutes in average. With the help of teacher interview form consisting of 33 semi-configured questions, information on the difficulties experienced by preschool teachers in performing music activities was received and perspectives and experiences of the participants were benefitted to the utmost. Next, upon the possibility of information that the participants would like to add or drop, interview forms were redistributed to the participants; some of the participants made the necessary additions while others dropped some information out of the interview forms. Yet, including the direct quotations from individuals and explaining the results on the basis of these quotations are important for validity according to Wolcott (1990). Therefore, some information gathered by the research was presented as it is in order to secure realism (in: Kesici, 2007b: 368).

\section{4. Data Analysis}

The derived qualitative data was analyzed with content analysis technique. The basic purpose of content analysis is to reach conceptions and connections that can explain derived data. Thus, derived data should firstly be conceptualized, then in compliance with these concepts they should be logically formed and the themes explaining the data should be determined accordingly. Therefore, by means of content analysis, derived data is tried to be identified and the fact that can be found in these data are tried to be located. Combining kindred data within the frame of certain concepts and themes and interpreting them via forming in an understandable way underlie content analysis (Yildırım and Şimşek, 2011: 227). Comments of participants were applied in written into semi-configured forms and were enumerated. In order to determine the comment tried to be pointed, data is conceptualized and coded in the form of words, sentences and paragraphs within the scope of research purpose and interview questions; then each theme and sub-theme are reflected in percentages. Nvivo2, which is a computer-assisted qualitative data analysis programme, is used for codification process. According to Coolican (1992), percentages in the qualitative 
Kılıç, I., Topalak, Ş., \& Yazıcı, T. (2017). A study of the difficulties that preschool teachers' experience in performance of musical activities in terms of various variables. Journal of Human Sciences, 14(1), 441-456. doi:10.14687/ihs.v14i1.4272

researches cannot be statistically used as in the quantitative researches. Percentages in qualitative researches are used for the purpose of putting in order and suggestion by qualitative research's nature (in: Kesici, 2007b: 368).

\section{Findings}

Table 1

Music Centre

\begin{tabular}{cll}
\hline Theme & Subthemes & Participants \\
\hline \multirow{3}{*}{$\begin{array}{l}\text { U. } \\
\text { Presence of Music Centre }\end{array}$} & T2, T3, T4, T5, T9, T11, T13, T14, T16, T17, T18, \\
T20 & $\begin{array}{l}\text { Presence of Instruments in } \\
\text { T1, T2, T3, T4, T5, T7, T9, T10, T11, T13, T14, } \\
\text { T15, T16, T17, T18, T19, T20 } \\
\text { Music Centre }\end{array}$ \\
$\begin{array}{l}\text { Effective Use of Music Centre } \\
\text { in Activities }\end{array}$ & $\begin{array}{l}\text { T1, T3, T4, T5, T6, T7, T10, T13, T14, T16, T17, } \\
\text { T18, T19, T20 }\end{array}$ \\
\hline
\end{tabular}

The distribution of participant teachers in Table 1 can be observed by subthemes in relation to music centre (music corner). 12 teachers have expressed their thoughts about subtheme "Presence of Music Centre". Except of T4, T5, T9, T11, T14, T17, T19 (7 participants), participants stated that music centers are available as only a centre name and those don't have sufficient tools and equipment. Other teachers in study stated that there are no music centers. Some expressions from teachers are as: "There is a place in wardrobe where we put our undershirts" (T14); "There is a corner where covers rbythm devices" (T9); "We've got a place as a board mounted on the wall, but use of it is not in a close centre. It is up there" (T20); "We've got a place with only a name" (T13); "No, we don't have anything other than a text of Music Corner" (T1).

This statement above shows that music centers in preschool institutions where study group works are extremely insufficient and there are physical obstacles in performance of music activities.

17 participants have expressed their thoughts about another subtheme "Presence of Instruments in Music Centre". Only 4 participants (T5, T9, T11, T17) stated that sufficient number of instrument is available for children to use them in music activities. 7 participants (T4, T7, T14, T16, T18, T19, T20) stated that instruments are available in their class to inform children, but they are not sufficient for children; other participants stated that they have no instrument. Those comments are as: "We've got sufficient tools. There are maraca, steel triangle. Also, our school has a music room" (T11);"There are necessary materials inside. There are cymbal, maraca, xylophone, but they are not sufficient, there are only samples" (T4); "We bought some instruments with our own means, but many of them are broken" (T16); "We've got a couple of rbythm bars, 2 maracas, 1 tambourine and steel triangle. They are not sufficient for children, when we would like to carry out activities." (T18); "We've no instrument" (T6); "We've maracas, drums, cymbals that we made using waste materials. We have a corner covering these instruments. There is also a music class in our school. There are a lot of instrument there. But, we cannot use there. We use the instruments that we made." (T10); "There are only maracas, which are made of waste materials, and cymbals which are made of crown corks" (T15).

When the thoughts about this subtheme are considered, it can be said that study group does not have necessary music activity materials in a preschool institution.

When subtheme "Effective use of music centre" is assessed, 14 teachers are determined. 4 (T3, T5, T7, T16) of these teachers use music centre in their activities, but other teachers do not use available music centers in their music activities, and also they stated that "We do rhythm practices when I perform music activity, then I play flute and sing, they repeat" (T3); "Some maracas that we made together with children are there, also we've got a tambourine. However, children use them as toys in their free time activities." (T1); 
Kılıç, I., Topalak, Ş., \& Yazıcı, T. (2017). A study of the difficulties that preschool teachers' experience in performance of musical activities in terms of various variables. Journal of Human Sciences, 14(1), 441-456. doi: $10.14687 /$ ihs.v14i1.4272

"I cannot say I use it effectively" (T4); "I don't use instruments in music centre to get them played, I just use them to introduce them and advertise their sounds. The reason is that I cannot play them well and I don't want to incorrectly teach children." (T14); "I don't use these instruments in activities, I just use them for free time activities to allow children to play games" (T17).

When thoughts are assessed, it is observed that music centre is not effectively used in preschool institutions, also they are commonly used for gaming activities.

Table 2

Music Activities

\begin{tabular}{|c|c|c|}
\hline Theme & Subthemes & Participants \\
\hline \multirow{9}{*}{ 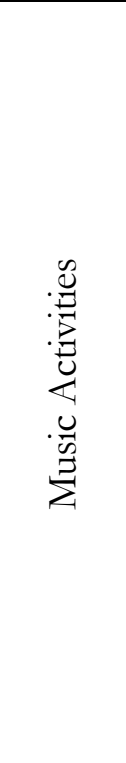 } & Including rhythm activities & $\begin{array}{l}\text { T3, T5, T6, T7, T9, T10, T11, T12, T15, T16, T17, } \\
\text { T19, T20 }\end{array}$ \\
\hline & Difficulties in rhythm activities & $\begin{array}{l}\text { T1, T2, T3, T4, T5, T6, T7, T8, T9, T10, T11, T13, } \\
\text { T14, T15, T16, T17, T18, T19, T20 }\end{array}$ \\
\hline & $\begin{array}{l}\text { Use of accompanying } \\
\text { instruments in activities }\end{array}$ & T3, T20 \\
\hline & $\begin{array}{l}\text { Use of percussion instrument } \\
\text { in activities }\end{array}$ & T6, T19 \\
\hline & Difficulties in musical games & T1, T9, T10, T13, T17, T20 \\
\hline & Difficulties in singing activities & $\begin{array}{l}\text { T1, T3, T4, T5, T7, T8, T10, T12, T13, T15, T16, } \\
\text { T18, T19, T20 }\end{array}$ \\
\hline & Including listening activities & T2, T3, T4, T5, T11, T10, T14, T15, T16, T29, T20 \\
\hline & $\begin{array}{l}\text { Failure in listening activities } \\
\text { due to difficulties }\end{array}$ & T1, T6, T7, T8, T9, T12, T13, T17, T18 \\
\hline & $\begin{array}{l}\text { Protection of available tools } \\
\text { and equipment }\end{array}$ & $\begin{array}{l}\text { T1, T3, T4, T5, T6, T7, T8, T9, T10, T11, T14, T15, } \\
\text { T16, T17, T18, T19, T20 }\end{array}$ \\
\hline
\end{tabular}

In Table 2, subthemes in relation to music activities theme of teachers take place. At the end of interviews performed, it's been determined that all teachers perform sound-breathing events, they do not meet any problem. Similarly, all teachers use musical games in their activities.

According to Table 2, 13 participants of study group use rhythm training in their activities. Furthermore, following comments from 4 participants of study group (T7, T9, T17, T20) are attractive:

"I am implementing, but I cannot create application-oriented activities together with children. For this reason, I am using more free activities" (T7); "I am setting children free to support their creativity in rbythm activities. I don't direct children. They apply the rhythms however they feel" (T9); "I let them to move free for it. They freely beat the rbythms, I don't direct them. They create the rbythms by themselves." (T17); "We don't apply very difficult activities. Sometimes, I am learning songs' rhythms from children, also they apply the rbythms better" (T20).

In fact, the children, from their birth, have skills to easily sense rhythms and react; very important developments in children such as timing feeling, increasing in concentration time, improvement of memory, ear and hand coordination, learning listening, learning group study can be observed due to rhythm training. Moreover, the training with rhythmic games provide more permanent and effective learning environment.

The thoughts of 9 participants who apply rhythm activities are as: "I want them to clap their hands as to song's tempo when we sing. However, I don't make different study. I don't do that with any material or I don't make any activities for only rbythm." (T2); "At the beginning of the term, I wanted them to be acquainted with each other 
Kılıç, I., Topalak, Ș., \& Yazıcı, T. (2017). A study of the difficulties that preschool teachers' experience in performance of musical activities in terms of various variables. Journal of Human Sciences, 14(1), 441-456. doi:10.14687/ihs.v14i1.4272

by beating time with their hands, but I did not do different activity" (T6); "I am applying, but it's too difficult to create application activities with the children" (T7); "In drama course, I got training of Orff, I am using this training as much as I can do. By wanting them to beat their knees with their hands, I am trying to do that by sounds" (T16).

According to these findings it can be said that rhythm activities are not sufficient. Moreover, thoughts of teachers show that rhythm activities are not regularly carried out, also they accidentally carry out these activities.

"Except of T12 in "Difficulties in Rhythm Activities", all participants have difficulties and stated that: "I use the moves of hand, finger and foot for rbythm activities. I use such activities to call children attention. Generally, I try to call their attention by slow or fast rbythms as to storyline, when I tell a story and then I continue to read a story. I have no difficulty" (T12); "I have rbythm devices, I tried to use them; but the children cannot use them and sing a song at the same time. They were bored and gave up using this method, because they got annoyed of sounds, noises they made. I was trying to do that more in the first years since I graduated, but now I am not, because I don't know how to arrange rbythm activities for children. I wasn't educated about it in the university. I failed when I tried to use for children the rbythm patterns I learnt. I did not know how to adapt what I learnt to preschool children. So, I gave up using it in my activities" (T4); "We started by counting with rbythm bars. I am using rbythms with simple songs. In time, they improve the rbythms a little. I have many difficulties in activities, because I don't know what to do and how to diversify. I don't do anything other than very simple rhythms. I don't do that every time" (T5); "I joined in rbythm workshop studies during three courses and I saw the benefit of it. Furthermore, these studies were compatible our level, this was not for preschool. The activities I learnt are difficult for children. I am trying to simplify" (T7); "I don't know how to make rbythm studies for children. I let them clap, but they irregularly do that. I think that their creativity improves in this way. They clap their hands however they like. Furthermore, I merely let them do that. Maybe, one time a year" (T8).

When thoughts about this subtheme are assessed, it's determined that all study group teachers have difficulties in rhythm activities in preschool institutions, these difficulties rise, because they don't know how they can do rhythm studies; how they diversify these studies and which rhythm studies should be carried out as to age and development level of children.

"2 participants (T3, T20) touched on subtheme "Use of Accompanying Instruments in Activities" and stated that they can simply play electronic orphan, although they did not had education of it, and also they sometimes play it for children in the class: "I have a small orphan in my house, sometimes I bring it to class and play some songs simply" (T3); "I sometimes use an orphan. In order to create awareness I play some simple songs I know. Besides, I don't perform music hours regularly” (T20).

When all study group is considered, it can be said that use of accompanying instruments are almost not used in activities.

"There are 2 participants (T6, T19). Those do not include percussion instruments in their activities and stated that: "They lose attention, when we work with instruments such as rbythm bars and tambourine, also they lose interest and start to play another things. Accordingly, I don't use these instruments" (T6); "I don't know bow to play instrument. In activities, I never use any instruments including rbythm instruments"(T19).

In the light of thoughts about this subtheme, it is determined that percussion (rhythm) instruments are not used in preschool institutions, they are mostly not available in classes or they are used to introduce to children or used as toys in free time activities.

It's that 14 participants give their thoughts about subtheme "Difficulties in Song Activities". Some of these thoughts are as: "We sometimes don't know the melodies in teaching songs. For instance, a child could learn the same song with different melody in the class of different teacher; but you teach it with different melody. This time, this child says 'But I know this song with different melody' and then you cannot correct wrong melody. Moreover, you cannot know which melody is true. We are getting confused. Generally, the melodies are created in the 
Kılıç, I., Topalak, Ș., \& Yazıcı, T. (2017). A study of the difficulties that preschool teachers' experience in performance of musical activities in terms of various variables. Journal of Human Sciences, 14(1), 441-456. doi:10.14687/ihs.v14i1.4272

eyes of teacher, not as to notes" (T10); "Generally, we sing a hearsay song or we assimilate songs. Accordingly, I teach the same song differently, so differently does one of my friends; all of us assimilates. Children learn it very well" (T12); "I don't know the notes. I cannot learn new songs. I am trying to teach the songs I know, because I cannot not know rhythms and melodies of other songs, or I compose them by myself to give the concepts, if the lyrics are suitable for educational attainment. I can say I teach every song in this way. Every year, we teach the same song with more different ways. It is a little funny, but it's true" (T19).

As seen in participants' thoughts, the ultimate difficulty in such activities is that teachers cannot teach the wrong melodies of songs. This shows that song activities in preschool institutions are not truly and regularly managed.

Thoughts of 11 participants about subtheme "Use of Listening Activities" have been determined. Some thoughts of these teachers who use listening activities are as: "I mostly make drama studies. They lie on the ground. I want them to imagine accompanied with music. Genres are generally classical" (T3); "I use relaxation activities. In the past, I let them listen classical music, but they were bored. They did not like it, and they like upbeat music. If I have got a song in relation to educational attainment that I will teach, we search this song on internet and listen it. Then, we learn it together" (T4); "I let them listen the songs we learnt, when we do art activity" (T11); "I use radio for music during our relaxation activities; I generally use CD player, when I want them to listen the songs for children that I will teach" (T19).

The thoughts above show that the activities for listening are principally drama teaching or singing teaching by ear, but teacher use it by reckoning as listening activity.

"9 comments have been determined in subtheme "Failure in Listening Activities due to Difficulties". The thoughts of participants in this scope are as: "I haven't done any listening activities this year. Children do not like it. It is too difficult to choose the songs in which they are interested. In the past, I wanted to perform it during their story hours, but they did not like it. Last year, I tried to make them listen to classical music. Some of children fell asleep. I made them listen for 40 minutes. They said they were bored. I never did it again" (T6); "I cannot say I do that. Children are getting bored, it is too difficult to determine when and what I can make them listen. We don't know how to choose certain songs that help children to love and go towards acculturation" (T7); "I don't think that this activity can be applied successfully. Children do not listen to music in silence and they are getting bored" (T12).

The thoughts above show that teachers have difficulty to choose songs that are listened by children without boring; to determine the time of listening activity; also they have difficulties how to apply the activity.

Regarding to subtheme "Protection of Available Tools and Equipment", 17 of teachers have difficulties in protection of available tools and equipment, and they mentioned as following. "This really a problem. We've got a period of time called free time. In this period, children are free to play in every place. Children enjoy musical instruments and want to play them. This interest does not depend on music, but they bave fun by beating maracas together to make sound and also they use tambourine as crown on their heads. Namely, they use instruments for playing tools, not musical purpose. Some children are interested in drum, they want to beat out. Furthermore, other children are troubled with these sounds. For that reason, we cannot allow them to beat out" (T4); "Children try to bang instruments together. On the other hand, if there was a place where instruments are in safe and realized as a lesson material, awareness of children would improve and they wouldn't damage materials. Now, they perceive them as toys and damage instruments" (T6); "Some fiends show sensitivity to instruments, but some of them doesn't, whereas we use them collectively. Some instruments are broken. Also, children do not want to work with broken materials" (T10).

The most important reason of failure in healthy and proper performance of activities in preschool institutions where study group works is that the children perceive tools and equipment as toys, because tools and equipment cannot be protected and used. The reason of this perception is that materials do not take place in music centre and also teacher cannot use materials in their activities. 
Kılıç, I., Topalak, Ş., \& Yazıcı, T. (2017). A study of the difficulties that preschool teachers' experience in performance of musical activities in terms of various variables. Journal of Human Sciences, 14(1), 441-456. doi:10.14687/jhs.v14i1.4272

Table 3

The opportunities that should be provided by school

\begin{tabular}{|c|c|c|}
\hline Theme & Subthemes & Participants \\
\hline The opportunities that should & $\begin{array}{l}\text { Equipment and } \\
\text { procurement }\end{array}$ & $\begin{array}{l}\text { T1, T2, T3, T4, T8, T10, T13, } \\
\text { T16, T18, T19, T20 }\end{array}$ \\
\hline be provided by school & $\begin{array}{l}\text { Conformance of class } \\
\text { environment to activities }\end{array}$ & $\begin{array}{l}\text { T3, T5, T6, T7, T9, T10, T13, } \\
\text { T16, T17, T18, T20 }\end{array}$ \\
\hline
\end{tabular}

The distribution in the scope of them "The opportunities that should be provided by school" by subthemes is shown in Table 3. When thoughts about subtheme "Tool and equipment procurement" are considered, it's determined that 11 participants have difficulties in tools and equipment procurement. Some of these thoughts are as: "We have no sufficient tools and equipment. We inform related authorities about our needs, but we cannot get positive results. So, we want other schools to belp us. It is not easy to procure those materials. Moreover, we don't have any family support due to environmental conditions. For this reason, we cannot make up our shortage" (T2); "We have no any tool and equipment in our school. We have difficulties to procure. We bave no sufficient tools and equipment for not only music activities, but also other activities" (T8).

When subtheme is considered, it's determined that teachers charge financial opportunities with their difficulties.

11 participants who gave their thoughts about "Conformance of class environment to activities" mentioned that the classes are too small and insufficient to perform activities. Some of these thoughts are as: "My class is too small to perform activities. Also, class size is too much" (T7); "My class is too small. I have to get all tables out of class, when I perform activities. I don't perform music activities when other activities are not suitable in a day, because, like I said, I have to make special preparation" (T20).

Table 4

Interest and Attitude of Parents in Music Activities

\begin{tabular}{|c|c|c|}
\hline Theme & Subthemes & Participants \\
\hline 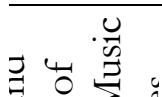 & $\begin{array}{l}\text { Parents' indifference in Music } \\
\text { Activities }\end{array}$ & T1, T2, T7, T10, T14, T18, T19, T20 \\
\hline$\underset{E}{\tilde{E}} \cdot \Xi$ & $\begin{array}{l}\text { Interest of parents in necessity of } \\
\text { music activities }\end{array}$ & T9, T11, T17, T18, T20 \\
\hline 艺苛 & $\begin{array}{l}\text { Interest of parents in music } \\
\text { activities }\end{array}$ & $\begin{array}{l}\text { T1, T2, T3, T4, T5, T6, T7, T8, T9, T10, T11, T12, } \\
\text { T13, T14, T15, T16, T17, } 18\end{array}$ \\
\hline
\end{tabular}

Distribution of theme "Parents' indifference in Music Activities" by subtheme is shown in Table 4. According to table data, teachers' assessment about subtheme "Attitude of parents in music activities" can be observed. A great majority of teachers mentioned that parents have positive attitude in music activities, but 8 teachers in the table mentioned that parents have no attitude in music activities and said that: "Parents are not interested in music activities. Until today I have seen that parents are interested in their children's success in literacy preparation activities, but I have never seen that they are interested in children's success in music activities" (T1); "They have no interest and expectation in music activities" (T2); "They are not interested. They always want their children to know how to read and write. They think that music activities are not useful, but they always care about mathematic and writing activities" (T14).

The thoughts of T14 in this subtheme is remarkable. When all study group is considered, it can be said that parents generally have positive attitude to music activities. 
Kılıç, I., Topalak, Ş., \& Yazıcı, T. (2017). A study of the difficulties that preschool teachers' experience in performance of musical activities in terms of various variables. Journal of Human Sciences, 14(1), 441-456. doi:10.14687/jhs.v14i1.4272

When subtheme "Interest of parents in necessity of music activities" is assessed, only 5 teachers said that parents are familiar with positive impact of music activities on children's development: "Parents are familiar with positive impact of music activities on especially language development of children. Parents are knowledgeable about if" (T11); "I think that we have parents who know that all kinds of activity would be useful for children, because the children bave education in schoop" (T18). The teachers, who think that parents are not familiar with importance of music activities, mentioned that "I don't think they find music activities necessary. They don't take heed of what their children learn in the school on the basis of activities. I don't think that they know how these activities will be important for children's life" (T16); "One of parents is a class teacher and her child is interested in music. I have recommended her to help her child to play an instrument. Furthermore, child's mother told me "I don't want my child to make an effort for a bouse of cards". I think it is weird, because this person is a class teacher and she thinks that interest of her child in music is a house of cards" (T10).

T10's assessment about this subtheme is in accord with T14's words in subtheme Parents' Indifference in Music Activities. These comments show that parents of children in preschool education in preschool institutions are not familiar with the support of music activities for development of children.

"18 of participants in subtheme "Interest of Parents in Music Activities" mentioned that parents are interested in music activities. Furthermore, 11 of these teachers (T1, T2, T4, T5, T8, T10, T12, T13, T14, T15, T18) emphasize that parents especially care about year-end activities. Some of these comments about this subtheme are as: "They care about. Especially in year-end activities, they want to see the success of their children" (T5); "Sure, they care about, because they are fond of happiness of their children" (T6); "I just know that they are happy to see their children in year-end musical demonstrations or to see their children singing a new song in their houses" (T18).

Other 2 participants mention that they haven't felt any interest.

When the data about subtheme are considered, it can be said that parents generally care about music activities; they want especially join year-end activities, because they are happy to see their children in social activities, accordingly parents care about year-end activities more.

Table 5

\begin{tabular}{|c|c|c|}
\hline Theme & Subthemes & Participants \\
\hline \multirow{3}{*}{$\begin{array}{l}\text { Difficulties depending on } \\
\text { School Management }\end{array}$} & $\begin{array}{l}\text { Expectations of school from } \\
\text { music activities }\end{array}$ & T1, T2, T3, T5, T8, T12, T13, T20 \\
\hline & $\begin{array}{l}\text { Expectations for year-end } \\
\text { activities }\end{array}$ & $\begin{array}{l}\text { T4, T6, T7, T10, T15, T16, T18, } \\
\text { T19 }\end{array}$ \\
\hline & $\begin{array}{l}\text { Cooperation with other } \\
\text { teachers for music activities }\end{array}$ & $\begin{array}{l}\text { T1, T2, T3, T4, T5, T7, T9, T10, } \\
\text { T11, T12, T13, T14, T16, T17, T20 }\end{array}$ \\
\hline
\end{tabular}

Regarding to subtheme "Expectation of School Management from Music Activities", 8 teachers mention that school management does not expect anything from music activities. Common thoughts: "They don't expect anything. All they expect that we regularly apply our lessons" (T2). Moreover, teachers mention that school management is interested in only year-end music activities; "They have never required any special thing for activities until today, but we made special activities for special days such as end of year, April 23th or mother's day" (T7). "Only musical plays are required for certain days. Apart from that, they never intervene with us about how we make activities in lessons" (T19). 
Kılıç, I., Topalak, Ş., \& Yazıcı, T. (2017). A study of the difficulties that preschool teachers' experience in performance of musical activities in terms of various variables. Journal of Human Sciences, 14(1), 441-456. doi:10.14687/jhs.v14i1.4272

Data from this subtheme show that school managers generally have positive attitude to music activities, but they have no an expectation from these activities.

Regarding to subtheme "Cooperation with other Teachers for Music Activities", 15 participants cooperate with other teachers. Teachers mentioned as: "I get help from music teacher in the school. I also get help from other teacher friends (community). One of my friend may teach a song, when I don't know it. We try to help each other" (T3); “We prepare for ceremonies together" (T11).

Comments show that the cooperation between teachers are generally for supporting each other for an unknown song.

Table 6

Difficulties depending on teacher

\begin{tabular}{|c|c|c|}
\hline Theme & Subtheme & Participants \\
\hline \multirow{8}{*}{$\begin{array}{l}\text { Difficulties } \\
\text { depending on } \\
\text { teacher }\end{array}$} & $\begin{array}{l}\text { Determining the kind of } \\
\text { music activities }\end{array}$ & T5, T6, T12, T13, T14, T17, T19, T20 \\
\hline & $\begin{array}{l}\text { Knowing Preschool Music } \\
\text { Education Methods }\end{array}$ & T3, T7, T13, T16, T18, T19 \\
\hline & Using Voice (singing) & T1, T2, T7, T12, T13, T14, T15, T19, \\
\hline & $\begin{array}{l}\text { Having Basic } \quad \text { Music } \\
\text { Knowledge }\end{array}$ & $\begin{array}{l}\text { T1, T5, T8, T9, T10, T12, T13, T14, T16, } \\
\text { T17, T19 }\end{array}$ \\
\hline & Competence of & \\
\hline & $\begin{array}{l}\text { Teaching in Higher } \\
\text { Education }\end{array}$ & T14, T15, T18, T20 \\
\hline & Having Sufficient Repertoire & T2, T4, T5, T9, T11, T17, T18, T20 \\
\hline & $\begin{array}{l}\text { Implementing } \\
\text { Activities }\end{array}$ & $\begin{array}{l}\text { T1, T2, T3, T4, T6, T7, T8, T9, T10, T11, } \\
\text { T12, T13, T14, T15, T16, T17, T18, T19, } \\
\text { T20 }\end{array}$ \\
\hline
\end{tabular}

Distribution of theme "Difficulties depending on teachers" by subthemes is shown in Table 6 . Interviews with teachers show that none of teachers can play an instrument, but they have no difficulties to prepare musical plays, and they can reach the resources through internet, if they require. This shows that technological opportunities of today are actively used in study group preschool education institutions.

Regarding to subtheme "Determining the Kind of Music Activities", 8 teachers said: "I may have problems, if I don't make preparation in advance. You may have difficulty, if you don't get ready in advance. I must make a plan by going through what I learnt from my trainings. Generally, I don't know the activity in the plan as well. I adapt, simplify the activity for children, even I make it up. I give importance to children's thoughts, and then I keep, if they like" (T6); "I don't know how I begin, finish music activities and how to draw attention in activities, this is a problem that I have" (T17); "I don't think I can properly implement music activities. I guess my teaching is too weak" (T19).

The thoughts about this subtheme show that teachers have difficulties to determine the kind of music activities due to lack of their knowledge.

Regarding to subtheme "Knowing Preschool Music Education Methods", 6 participants express their thoughts. These thoughts show that teachers only know Orff method among the methods such as Orff, Dalcroze, Kodaly, but they do not apply this method: "I know Orff, but don't know Dalcroze. I have never heard it. I know Orff, but I have difficulties to teach children, it too difficult to express and apply most properly for children, or it may be easy, but we don't know" (T7). "I had a little education about Orff. Furthermore, this education was one-hour theoretical. I've never heard another one. I cannot know how to apply Orff 
Kılıç, I., Topalak, Ș., \& Yazıcı, T. (2017). A study of the difficulties that preschool teachers' experience in performance of musical activities in terms of various variables. Journal of Human Sciences, 14(1), 441-456. doi:10.14687/ihs.v14i1.4272

method for preschool level. I have a common knowledge about it. I don't say I can apply it very welp" (T16). "I don't know these methods. I wasn't trained on them. I don't apply them, because I have no knowledge. I only heard about Orff method, bonestly, I don't know how to apply it. I think that preschool teachers must have drama and rhythm study and education" (T19).

All of other participants mentioned that they've never heard about these methods. According to thoughts about this subtheme, it can be said that none of teachers uses these methods and even they have no knowledge.

Regarding to subtheme "Using voice (singing)", 8 comments are as: "I have no nice voice, I have difficulty to sing a song, and like I said before, sometime I sing the songs by making them up" (T7); "My voice is not so good. I know that I cannot stick to original melody of a song" (T12); "I cannot use my voice consciously" (T19).

Thoughts about this subtheme show that most teachers can use their voices.

Regarding to subtheme "Having Basic Music Knowledge", 12 thoughts have been expressed. Teachers are the opinion that they don't have sufficient basic music knowledge: "I have common knowledge, but I don't think it is enough" (T1); "I have rough edges, I don't know musical notation" (T3); "I think I am not sufficient, because I don't have education" (T8).

Since $60 \%$ of teachers do not have basic music knowledge, the music activities cannot be performed properly. This is root cause of it.

When the thoughts about subtheme "Competence of Music Teaching in Higher Education" are considered, only 4 teachers find higher education institutions successful. Their thoughts: "My music education in university was sufficient. Our lecturer wanted us to concern ourselves about playing an instrument." (T14); "I think that music lessons are suitable for related field and sufficient. We prepared musical demonstrations, materials and learnt songs." (T20). T15 and T18 mentioned that the education is sufficient in theory, but it's not sufficient in practice: "It was sufficient in theory, but it was never sufficient in practice. We learnt bow to play flute and use notes, but I have never play a flute after my graduation. Also, I have never tried to play a new song by using its notes. I am teaching new songs by using a CD or creating its melody. If it had been sufficient in practice and if I had gotten education of children songs, finger plays, rhythm activities, it would have been better" (T15); "It was good in theory, but there were insufficient lessons in practice. I guess that this program must be reviewed and it must be made suitable for preschool activities. Moreover, children may be educated to play an instrument. One of our basic problems is inability to play an instrument" (T18).

16 of participants mentioned that music lessons in their higher education institutions were not sufficient. Moreover, the teachers graduated from Open Education Institutions could not get sufficient education, since they passed their exams by only memorizing education books: "I think that I already completed my university education when I was at high school, because I graduated from Open Education. We always memorized the lessons when we were learning in open education system" (T11); "Sure, it wasn't sufficient. I read theoretical books and passed the exams. Now, I cannot remember anything in these books" (T13).

Thoughts of teachers who graduated from Faculty of Education are as: "It was definitely insufficient. There must be more music lessons. We use the music in our activities. We must have sufficient musical knowledge to use more musical things in our lessons. Hours and terms of lesson in faculties must be increased" (T1); "It wasn't sufficient. It had to depend on more practice. Basic knowledge is important, but we cannot be sufficient when we don't know how to implement it in accordance with age groups" (T7). In the scope of this subtheme, it's determined that teachers do not find their education sufficient.

Regarding to subtheme "Having Sufficient Repertoire", 8 teachers gave their thoughts: "I have sufficient repertoire, because I have been working as a teacher for 23 years" (T2); "It's enough, I can teach two songs in a day. We are looking for songs through computer. I learn it before, and then I teach them" (T4); "I have a 
Kılıç, I., Topalak, Ş., \& Yazıcı, T. (2017). A study of the difficulties that preschool teachers' experience in performance of musical activities in terms of various variables. Journal of Human Sciences, 14(1), 441-456. doi:10.14687/ihs.v14i1.4272

notebook, I write the songs I know. I sing these songs in the activities. Sometimes, I create the melodies of songs for myself, but I have many songs in my notebooks" (T17).

12 of participants mentioned that they have no sufficient repertoire: "It is not sufficient. I use available material" (T1); "All of our repertoire can be used for different students, because students change every time. But, it destroys the necessity of new songs, so you become blunt." (T10); "I want to improve my repertoire; we teach the same things every year. I want to learn and teach different things" (T12).

The thoughts in this subtheme show that teachers do not find their repertoire sufficient to perform the activities.

Regarding to subtheme "Implementing Music Activities", 19 teachers gave their thoughts. In this scope only T5 stated "I think that preschool teachers must get a qualified music education, and these activities must be implemented by only preschool teachers. Because, we don't assess an activity for only its scope. We must give importance to all activities when we prepare an activity, also we can understand the needs of children better. Accordingly, these activities must be implemented only by us, but we must get a good music education"; other 19 teachers mentioned that implementing music activities by music teachers is necessary to implement more active and proper music activities: "In some schools, branch teachers are necessary to implement physical education or English activities; it would be better, if music activities are implemented by music teachers" (T6); "This is necessary. No matter how we try to do that, we cannot prepare a more proper music activity than a branch teacher. Maybe, they cannot be charged with all activities, but they can belp us to make better activities and more suitable music activities for other activities, so that activities can be better and more instructive. For us and children" (T7); "Since 0-6 aged children can have fast knowledge acquisition, implementing these activities by a branch teacher is very important. I guess this is the best way. We cannot implement these activities like a music teacher does" (T19).

The thoughts about this subtheme show that music activities must be implemented by music teachers.

Table 7

Difficulties depending on children

\begin{tabular}{lll}
\hline Theme & Subtheme & Participants \\
\hline \multirow{2}{*}{$\begin{array}{c}\text { Difficulties depending on } \\
\text { children }\end{array}$} & $\begin{array}{l}\text { Children Attitude } \\
\text { Instruments }\end{array}$ & T2, T5, T10, T11, T17, \\
& Using Instruments like a toy & T3, T4, T6, T7, T12, T14, T16, \\
& T19, T20 & T1, T7, T8, T13, T15, T18, T19 \\
\hline
\end{tabular}

Distribution of "Difficulties depending on children", which the teachers in preschool institutions have in music activities, is shown in Table 7 by its subthemes. In the interviews performed, all teachers expressed that their children are considerably interested in music activities. This is a positive finding proving that the children are disposed to join music activities. All participants mentioned that the children prefer common voice training more than individual voice training, because they feel themselves safe.

Regarding to subtheme "Attitude of Children to Instruments", 5 participants gave their thoughts. They mentioned that the children have positive attitude to instruments: "They love beating out and moving with songs. An instrument attracts their attention, when they see an instrument, they want to explore if' (T2); "They love hearing different voices" (T5).

Regarding to subtheme "Using instruments like a toy", 9 participants gave their thoughts: "Instruments attract their attention like a part of the game" (T4); "They care, but they are bored very fast. I cannot say that we know the instruments very well. We can only show their pictures on the internet, they prefer to use Orff 
Kılıç, I., Topalak, Ș., \& Yazıcı, T. (2017). A study of the difficulties that preschool teachers' experience in performance of musical activities in terms of various variables. Journal of Human Sciences, 14(1), 441-456. doi: $10.14687 /$ ihs.v14i1.4272

instruments for playing a game" (T7); "They use the instruments for only making noise in their games" (T16).

The thoughts of teachers above show that the children generally love using instruments like a part of their games. The children cannot learn purpose of their use, because teachers do not use instruments in their activities.

Regarding to subtheme "Describing Instruments", 7 participants gave their thoughts. In this scope, the teachers mentioned that they cannot show children the instruments due to impossibilities: "We cannot describe the instruments, for this reason, I don't know how much they are interested in instruments" (T1); "We cannot introduce the instruments to children. We have no instrument. We only showed their pictures, but they had a look and could not understand. They did not care about, because they could not see instrument and not hear its voice" (T8).

Table 8

Inservice Training

\begin{tabular}{lll}
\hline Theme & Subtheme & Participants \\
\hline & $\begin{array}{l}\text { Participating in inservice training } \\
\text { with regard to music activities }\end{array}$ & T5, T7, T9, T10, \\
& $\begin{array}{l}\text { Implementation of music activities } \\
\text { Inservice }\end{array}$ & $\begin{array}{l}\text { T1, T2, T3, T4, T6, T7, T8, T9, T10, T11, } \\
\text { by music teacher }\end{array}$ \\
Training & T20 T13, T14, T15, T16, T17, T18, T19, \\
& $\begin{array}{l}\text { Getting help from specialists in the } \\
\text { field of music }\end{array}$ & T3, T16 \\
& Getting inservice training & T1,.., T20 \\
\hline
\end{tabular}

In Table 8, distribution of theme "Inservice Training" by its subthemes is shown. Regarding to subtheme "Participating in Inservice Training with regard to Music Activities", 4 teachers gave their thoughts: "Through my own means, I participated in 3 periods of rbythm training" (T7); "In the scope of a project, I got training of singing, but I baven't participated in a different training" (T5); "There was one-day training of rbythm. I participated in it, but it was a theoretical training. Also, the class was very crowded. Obviously, I couldn't learn anything. I never understood how to implement in activities" (T9).

Other teachers in this study mentioned that they did not get any education about music activities, or did not participate in any seminar or study, and they have never heard about this kind of education.

Only 1 teacher gave a positive thought about subtheme "Getting help from specialists in the field of music": "Yes, I sometimes get help from music teacher in the school' (T3). Other 18 teachers have not gotten any help. This shows that study group do not get help, when they perform their activities.

Regarding to subtheme "Getting inservice training", all teachers gave a positive thought. In case of an inservice training, they would like to participate in such trainings, they think that this kind of trainings would enrich their activities: "I would like to participate. It helps me for not only children, but also my professional field. There must be trainings that is useful for us especially in seminar periods, that raises our professional knowledge" (T3); "I would love to do. In this way, I can create the activities more effective and productive. Now, we are performing without preparations. What we cannot do in activities arises from lack of knowledge, and it would raises our abilities, if we are able to get this kind of training" (T6).

The expressions above show that the teachers would like to improve themselves, and this kind of training shall be useful for music activities. This result shows that the teachers need inservice training, but they have no opportunities to participate in these trainings. Nevertheless, teachers would like to improve themselves in their professions and they feel the lack of this training, so this can be assessed as a positive result. 
Kılıç, I., Topalak, Ş., \& Yazıcı, T. (2017). A study of the difficulties that preschool teachers' experience in performance of musical activities in terms of various variables. Journal of Human Sciences, 14(1), 441-456. doi:10.14687/ihs.v14i1.4272

\section{Discussion, Results and Suggestions}

In this study that has been performed to determine difficulties against preschool teachers when they carry out music activities, when the findings that have been obtained by the way of interview with 20 preschool teachers are assessed, the following facts give result;

$65 \%$ of participants does not have a music centre, and also they have no materials to use music activities. Moreover, music centre is not be used effectively, it is commonly used as a playing centre. The indication of deficiencies with regard to music centers corresponds to indication in Karaküçük(2008) and Köksoy and Taş (2005) study about lack of music corner in preschool institutions. In other respects, since teachers in study group do not know how to do and diversify rhythm studies and which rhythm studies should be performed for children age and development levels, they have difficulties in performance of music activities, as a result, they perform accidental music activities. This finding corresponds to comment in the study by ÖzalGöncü (2010), which highlights that preschool teachers rarely perform rhythm studies; also Salı and others (2013) mention in their studies that teachers are not able to teach children how they can use rhythm tools. In a song activity, the most crucial difficulty is that the teachers are not able to reflect the melodies of songs (70\%). In a similar way, this fact corresponds to Koca's study (2013), which shows that teacher candidates have difficulties in melodic performances and interpretation dimensions; to Köksoy's and Taş's study (2005), which shows that teachers have difficulties in teaching songs. $30 \%$ of participants only knows Orff method among music education methods, but they cannot use it; 100\% has never heard about other methods such as Dalcroze, Kodaly. A similar fact in Göncü's study (2009) shows that preschool teachers do not use the methods in preschool music education. Also, Eren and Sağlam's study (2009) shows that Dalcroze and Kodaly methods are not used, this fact is similar to our study. However, Sağlam's study shows an opposite fact, which highlights that $51 \%$ of teachers in Sağlam's study uses Orff method, this rate of use depends on seminars about Orff method.

$60 \%$ of study group believe that they are not familiar with basic music knowledge. 16 of teachers $(80 \%)$ mentioned that the music education in higher education institutions is not sufficient. This fact corresponds to fact by Özkut and Kaya (2012), which highlights that music knowledge in undergraduate study is not sufficient. $60 \%$ of participants does not find their repertoire sufficient. $80 \%$ of teachers has not participated in an inservice training, seminar or study, $100 \%$ would like to participate in an inservice training about the music. This corresponds to fact by Ersoy and Dere (2012) which highlights that teachers in preschool education institutions need an inservice training. 95\% of participants think that music activities should be implemented by a music teacher. Furthermore, $90 \%$ has never gotten help from a specialist in the field of music. This fact corresponds to the fact by Özkut and Kaya (2012) which highlights that music activities should be performed my specialists, but preschool teachers do not lean to get help from music teachers.

2 teachers $(10 \%)$ mentioned that they cannot play accompanying electronic organ very well. $90 \%$ of teachers cannot give music education by using any instrument; the study by Köksoy and Taş (2005) also highlights that the preschool teachers are not able to musical instrument. More than half of preschool teachers $(55 \%)$ does not have proper classes to perform music activities. This fact corresponds to study by Eren and Sağlam (2009) which highlights that the classes, where music activities are performed, are not sufficient. $40 \%$ of teachers in study group thing that parents are not interested in music activities; 25\% things that parents care about music activities and find them necessary; $90 \%$ expresses that parents are interested in music activities, but $61 \%$ of teachers highlights that parents' interest depends on year-end activities. $40 \%$ of participants mentions that school managements have positive attitude to music activities, they have no expectation from such activities; $40 \%$ of teachers highlights that school managements have expectation from year-end 
Kılıç, I., Topalak, Ş., \& Yazıcı, T. (2017). A study of the difficulties that preschool teachers' experience in performance of musical activities in terms of various variables. Journal of Human Sciences, 14(1), 441-456. doi:10.14687/jhs.v14i1.4272

activities. $75 \%$ of participants cooperates with music teachers, when they perform music activities. $40 \%$ of participants has difficulties to determine the kind of music activities; $100 \%$ of teachers does not have any difficulty in preparation and implementation of musical games. Moreover, $100 \%$ of teachers does not have any difficulty in reaching required resources. $45 \%$ of teachers, who graduated from open education institutions, things that they have no sufficient knowledge, because they got education based on memorization. $60 \%$ of participants finds their repertoire insufficient.

All participants (100\%) highlights that the children are highly interested in music activities and also they prefer common voice trainings more than individual trainings; $45 \%$ expresses that the children use instruments like a toy; $25 \%$ expresses that the children care about instruments; $35 \%$ cannot introduce instruments to children.

Inservice trainings, seminars and studies must be organized to give sufficient knowledge to preschool teachers in performance of music education. Inservice trainings must aim at teaching musical activities by application and performed with not large groups but with small groups. The credits of music lessons in academic departments of preschool education must be increased, the academic students must be subject to more practical program in music education. Academic students in department of preschool education must be subject to repertoire practices, rhythm activities, Orff instruments; music activities in preschool institutions must be implemented with the help and guide of music teachers. What is more, portrayal of the general situation is possible through conducting the research in other provinces as well.

\section{References}

Çepni, S. (2009). Introduction to Research and Project Studies, ( $4^{\text {th }}$ Edition). Trabzon: Salih Çepni.

De L'Etoile, S. K. (2001). An In Service Training Program in Music for Child-Care Personnel Working with Infants and Toddlers. Journal of Research in Music Education, 49(1), 6-20.

Eisner, E. (2001). Music education six months after the turn of the century. Arts Education Policy Review, 102(3), 20-25.

Epstein, A. S. (2001). Thinking about art: encouraging art appreciation in early childhood settings. ERIC, 3(56), 38-43.

Erden, M. (1998). Introduction to Teaching Profession. Istanbul: Alkım Yayınları.

Eren, B., \& Sağlam, A. (2009).Determination and assessment of basic needs of music education in playschools of Bursa City. GEFAD, 29(3), 575-599.

Ersoy, Ö., \& Dere, Z. (2012).Assessment of implementation performed by teachers in playschools of Ankara City in the scope of music education. Ankara University, Journal of Faculty of Education Sciences, 45(1), 249-268.

Karaküçük, A. S. (2008). Assessment of physical/spatial conditions in preschool education institutions: Sivas City sample. Cumburiyet University, Journal of Social Sciences, 32(2), 307-320.

Karasar, N. (2012). Scientific Research Method. Ankara: Nobel Yayıncilik.

Kesici, S.. (2007a). Guidance and Counseling Needs of Second Grade Students in Primary Education. Educational Sciences in Theory and Practice, 7(3), 1301-1349.

Kesici, S. (2007b).Guidance and Counseling Needs of $6^{\text {th }}$, $7^{\text {th }}$ and $8^{\text {th }}$ Grade Students as Classified by School Branch Counselors. Selçuk University Institute of Social Sciences Journal, 17, 365-383.

Köksoy, M. A., \& Taş, M. A. (2005). Determination of thoughts of preschool teachers in preschool institutions about preschool music education (Niğde City sample). Gari University, Faculty of Education in Kirşebir, 6(1), $31-40$. 
Kılıç, I., Topalak, SS., \& Yazıc1, T. (2017). A study of the difficulties that preschool teachers' experience in performance of musical activities in terms of various variables. Journal of Human Sciences, 14(1), 441-456. doi: $10.14687 /$ ihs.v14i1.4272

Kyoung Kim, H. (2013). A comparison of early childhood preservice teachers' beliefs about music and developmentally appropriate practice between South Korea and the US. Australasian Journal of Early Childhood, Volume 38, Number 2, 122-128.

Oğuz, A. (2004). Constructivist Learning Methods in Higher Education. XII. Notices in Congress of Educational Sciences (Vol. I), Gazi University, Institution of Educational Sciences, (p.7998), Ankara.

Oktay, A., \& Zembat, R. (1994). Determining the situation of preschool education institutions in Istanbul. Marmara University, Faculty of Education, Journal of Educational Sciences, 6 (6), 23-34.

Ömeroğlu, E. (1997). An overview of mother training course in public education centers under Ministry of National Education. Gazi University, Faculty of Professional Education, Department of Child Development and Home Economics, Ankara.

Ömeroğlu, E., \& Yaflar, M. C. (2004). Preschool Education.Journal Görüs, 79-98.

Özal Göncü, İ. (2010). Basic Problems of Music Education in Preschool.Educational Journal, Kastamonu, 18 (2), 355- 362.

Özkut, B., \& Kaya, Ö. S. (2012). Assessment of Impact of academic music education on professional lives of preschool teachers in primary education schools. IJTASE, 1(1), 178.

Paquette, K., \& Rieg, S. (2008). Using music to support the literacy development of young English language learners. Early Childhood Education Journal, 36(3), 227-232.

Sal, G., Akkol, M. L., \& Oğuz, V. (2013). Problems against preschool teachers in music activities. Journal of Social Sciences, 15(2), 79-100.

Taner Derman, M., \& Başal, H. A. (2010). Qualitative and quantitative developments in preschool education and primary education from proclamation of republic to the present. Journal of International Social Researches, 3(11), 560-569.

Ünlü, M. (2001). Geographical Education to Students in Preschool Education Program. Journal Marmara Coğrafya, 4, 87-100.

Yıldırım, A., \& Şimşek, H. (2011). Qualitative Research Methods in Social Sciences, Ankara: Seçkin Yayıncilik. 